\title{
Cellmates versus family - the sense of belonging among tattooed prisoners
} Współwięźniowie kontra rodzina - poczucie przynależności wytatuowanych więźniów

\author{
Department of Personality Psychology and Forensic Psychology, Institute of Psychology, University of Gdańsk, Gdańsk, Poland \\ Correspondence: Mateusz Lammek, Department of Personality Psychology and Forensic Psychology, Institute of Psychology, University of Gdańsk, Bażyńskiego 4, 80-309 Gdańsk, Poland, \\ tel.: +4858523 4376, e-mail: mateusz.lammek@ug.edu.pl
}

Zakład Psychologii Osobowości i Psychologii Sądowej, Instytut Psychologii, Uniwersytet Gdański

Adres do korespondencji: Mateusz Lammek, Zakład Psychologii Osobowości i Psychologii Sądowej, Instytut Psychologii, Uniwersytet Gdański, ul. Jana Bażyńskiego 4, 80-309 Gdańsk, Polska, tel.: +4858523 43 76, e-mail: mateusz.lammek@ug.edu.pl

\begin{abstract}
Introduction: The sense of belonging in a group can be a form of adaptation to the conditions of prison isolation. However, excessive group identification could result in negative consequences for the identity of an individual. The sense of support in social relations is a significant personal resource of convicts. The social identity of convicted persons influences their behaviour, and thus the effect of penitentiary interactions. Hence, the aim of the study was to assess the sense of belonging in a group among convicts with body modifications. Methods: The research was conducted in penitentiary units at the District Inspectorate of the Prison Service in Gdańsk (Poland). Fifty-eight re-sentenced convicts participated in the study (36.2\% did not have body modifications, and $63.8 \%$ had tattoo/tattoos). The age of the respondents ranged from 18 to 62 years $(M=35.12$; standard deviation, $S D=10.98$ ). The participants completed the Group Identification Scale (Mael and Ashforth, 1992), the Identity Fusion Scale (Gómez et al., 2011) and the measure of identity fusion (Swann et al., 2009). Results: The study showed that convicts declare a very weak sense of belonging with their cellmates (55.2\%) and a very strong sense of belonging with their family (44.8\%). A relationship was observed between younger age and identity fusion; however, it was on the border of a significant statistical trend. Conclusions: Interpersonal relationships used as a personal resource in the social rehabilitation process can be extremely important for the probability of recidivism in the future. Especially, non-standard methods may allow convicts to test themselves in a new role. The self-concept should not be formatted through the prism of social stereotypes of prisoners, but with the simultaneous support of the family, which may strengthen socially acceptable behaviours.
\end{abstract}

Keywords: social identity, prisoners, family, social identification

Poczucie przynależności do grupy może być formą adaptacji do warunków izolacji więziennej. Jednak nadmierna identyfikacja grupowa może skutkować negatywnymi konsekwencjami dla tożsamości jednostki. Odczuwane wsparcie w relacjach społecznych stanowi znaczący zasób osobisty osób skazanych. Tożsamość społeczna osób skazanych wpływa na ich zachowanie, a tym samym na efekt oddziaływań penitencjarnych. Stąd celem pracy było określenie poczucia przynależności do grupy wśród skazanych, którzy posiadają modyfikacje ciała. Metoda: Badania przeprowadzono w jednostkach penitencjarnych na terenie Okręgowego Inspektoratu Służby Więziennej w Gdańsku. W badaniu wzięło udział 58 ponownie skazanych więźniów (36,2\% skazanych nie posiadało modyfikacji ciała, a 63,8\% miało tatuaż/tatuaże). Wiek osób badanych zawierał się w przedziale 18-62 lata $(M=35,12$; odchylenie standardowe, standard deviation, $S D=10,98)$. Uczestnicy badania wypełnili skalę identyfikacji z grupą (Mael i Ashforth, 1992), skalę fuzji z grupą (Gómez et al., 2011) oraz miarę fuzji tożsamości (Swann et al., 2009). Wyniki: Wykazano, że skazani deklarują bardzo słabe poczucie przynależności do współwięźniów (55,2\%) oraz bardzo silne poczucie przynależności z rodziną (44,8\%). Zaobserwowano - na granicy istotnej tendencji statystycznej - zależność między młodszym wiekiem a wyższymi wynikami na skali fuzji tożsamości. Wnioski: Wykorzystanie relacji interpersonalnych jako osobistego zasobu w procesie resocjalizacji może mieć niezwykłe znaczenie dla prawdopodobieństwa recydywy w przyszłości. Szczególnie niestandardowe metody mogą pozwolić skazanym na przetestowanie siebie w nowej roli. Formowanie obrazu siebie nie przez pryzmat społecznych stereotypów więźniów przy jednoczesnym wsparciu rodziny może wzmacniać społecznie akceptowane zachowania.

Słowa kluczowe: tożsamość społeczna, więźniowie, rodzina, identyfikacja społeczna 


\section{INTRODUCTION}

$\mathrm{D}$ etection of a committed crime and further actions, such as arrest, trial, sentence and imprisonment, occur in a long-time perspective, and stress becomes a permanent element of the life of suspects or convicts. The specificity of the prison environment forces convicts to adapt to and cope in a new, sometimes very difficult, situation. Under these conditions, an individual may perceive the situation as hostile, threatening and even dangerous. Belonging to a group could be considered as a way of adaptation, which may result in the loss of personal identity in favour of group identity, and body modification as its visual symbol. In its most extreme form, identity diffusion, can be characterised by the lack of a clear distinction between the personal self and social self (Swann and Buhrmester, 2015). The situation of isolation is not only an individual tragedy, but a membership in a socially excluded group reveals common features of the situation, among other things, through dependence on others and the lack of a sense of social usefulness (Bałandynowicz, 2011). A newly convicted person must go through the process of adaptation, which includes a specific "initiation" by convicts to test the reaction of the "freshman" (Kamiński, 2004). Therefore, the prison subculture has a special impact on the formation of self-esteem, not only through the prism of one's own personal attributes, but also based on the status and position as a group member (Debowska et al., 2017).

In the report on the social bonds of current and former convicts, the significance of personal maladjustment in the sphere of relations with others, and especially with the family, was associated with aggressive and antisocial behaviours (Kalinowski et al., 2010). Among the personal resources of an individual, the importance of emotional support perceived by convicts has been linked to satisfying relationships based on empathy and mutual concern (Niewiadomska, 2007).

Various scientific psychological studies have analysed the sense of social identity of prisoners in relation to cellmates. Research conducted by Boduszek et al. (2016) suggested that the development of criminal social identity results from the interaction of psychosocial factors, such as identity crisis, exposure to the criminal environment, the need for identification with a criminal group in order to protect self-esteem and personality traits. Identity crisis, as a natural developmental process, is associated with the exploration and contemplation of one's own role in society, when faced with challenge to the sense of self. Studies have shown that the perception of self through the prism of the committed crime and the sense of belonging to a criminal group is characterized by association with criminal friends (Boduszek et al., 2013). Although achieved identity can contribute to adaptation to new conditions, it may also have negative consequences for the self. Criminal identity of an egodystonic nature affects the prisoner's level of shame and embarrassment (Keith and Scheuerman, 2018), as well as reduced self-esteem (Asencio, 2011). However, it is possible that prisoners can simulate identity changes by creating relationships with other prisoners through interpersonal manipulation skills (Sherretts et al., 2016).

The significance of the exploration of social identity consisted in demonstrating that the stronger the identification with the deviant group, the more the rival group members were perceived as threatening, which increased the propensity for revenge (Vasquez et al., 2015). The results of these scientific studies adapted to possible intergroup behaviours in the prison setting may explain the increased number of acts of aggression of prisoners towards convicts perceived as members of a rival prison group/subculture.

Excessive identification with prisoners can be behaviourally expressed by body modifications characteristic for a criminal subculture. The efforts of prison officers to avert such behaviours are aimed at preventing social stigmatisation after serving a sentence. Studies have shown that people who experienced group-based rejection had poorer well-being and an increased sense of identification with a socially rejected group (Kyprianides et al., 2019). This effect will interfere with the possible process of achieving a non-criminal identity after serving a sentence.

Identity crisis, contemplation process, self-exploration, and, ultimately, achieving identity significantly affects behaviour, and thus the process of resocialisation and the probability of recidivism in the future. Hence, the aim of the study was to verify to which group (colleagues-cellmates or family) convicts who modified their body declare a stronger sense of belonging. Efforts were made to determine the intensity of the sense of belonging to the closest group of fellow inmates with whom the participants live on a daily basis, as well as in relation to members of the immediate family with whom they maintain contact during prison isolation. The intention of the research was also to reveal factors that could explain the variance of the obtained results.

\section{MATERIALS AND METHODS}

\section{Participants}

The research was conducted in penitentiary units of the District Inspectorate of the Prison Service in Gdańsk (Poland). A total of 58 men were included in the study. The participants were serving a prison sentence during the study. Prison officers selected convicts among penitentiary recidivists to ensure, as much as possible, equal proportions of the study group and the control group. Factors such as cognitive abilities and involvement in pro-social behaviours, such as participation in the study, were also significant in the selection. The analyses did not take into account the length of the imprisonment sentence. The questionnaires were 


\begin{tabular}{|c|c|c|c|c|}
\hline \multirow{2}{*}{} & \multicolumn{2}{|c|}{ Sense of belonging with cellmates } & \multicolumn{2}{c|}{ Sense of belonging with family } \\
\cline { 2 - 5 } & Rates & Percent & 3 & Rercent \\
\hline Very weak & $\mathbf{3 2}$ & $55.2 \%$ & 5 & $5.2 \%$ \\
\hline Weak & 14 & $24.1 \%$ & 5 & $8.6 \%$ \\
\hline Average & 6 & $10.3 \%$ & 19 & $8.6 \%$ \\
\hline Strong & 3 & $5.2 \%$ & $\mathbf{2 6}$ & $32.8 \%$ \\
\hline Very strong & 3 & $5.2 \%$ & $44.8 \%$ \\
\hline
\end{tabular}

Tab. 1. The rates of sense of belonging with 1) cellmates and 2) family

completed by convicts individually in a specially appointed room. The age of the convicts ranged from 18 to 62 years $(M=35.12$; standard deviation, $S D=10.98)$. As for the place of residence before imprisonment, $14(24.1 \%)$ participants lived in a rural area, $5(8.6 \%)$ in a small town, $24(41.4 \%)$ in a town, $13(22.4 \%)$ in the suburbs and $2(3.4 \%)$ in a city. The respondents were divided based on possession (or not) of body modifications, such as piercing or tattoos, treated as a conscious and social expression of identity. Among convicts, 21 (36.2\%) had no body modifications, and 37 (63.8\%) had body modifications (tattoos). Informed consent was obtained from each participant included in the study.

\section{Instruments}

Group Identification Scale (Mael and Ashforth, 1992; Polish version: Jaśkiewicz and Besta, 2014) is a tool used to measure group identification. This 5 -item scale was adapted to the context of cellmates. Items included for example: "When someone criticizes my cellmates, I feel personally insulted," "When I talk about cellmates, I usually say 'we' rather than 'they." Items were assessed on a seven-point Likert scale ( 0 = "I strongly disagree;" 6 = "I definitely agree." The scale has a high reliability index, Cronbach's alpha was 0.88 .

Identity Fusion Scale (Gómez et al., 2011; Polish version: Besta et al., 2014) measures the overlap between individual and group identity. The scale consists of seven items modified to the context of cellmates, such as: "My cellmates are me," "I have a deep emotional bond with my cellmates." Responds were given on a seven-point Likert scale ( 0 = "I definitely do not agree;" 6 = "I definitely agree"). The scale used in the study has a high reliability index, Cronbach's alpha was 0.911 .

The measure of identity fusion (Swann et al., 2009) was used to assess fusion through perceived "closeness with the group." The participants were asked to choose a picture which best represented their relationship with 1) cellmates and 2) family. The scale consisted of five symmetrical gradually overlapping circles $(0 \%, 25 \%, 50 \%, 75 \%$, and $100 \%)$.

\section{Data analysis}

Initially, descriptive statistics and frequencies were computed for all variables studied: age, body modification, group identification, identity fusion, and the sense of belonging

\begin{tabular}{|l|c|c|}
\hline \multicolumn{1}{|c|}{ Variables } & $\mathbf{2}$ & $\mathbf{3}$ \\
\hline 1. Identity Fusion Scale & $0.76^{*}$ & $0.53^{*}$ \\
\hline 2. Group Identification Scale & - & $0.43^{*}$ \\
\hline 3. Sense of belonging with cellmates & - & - \\
\hline${ }^{*} p<0.001$.
\end{tabular}

Tab. 2. Spearman's correlations (r) between identity fusion, group identification and sense of belonging

with 1) family and 2) cellmates. Then, a Shapiro-Wilk test was performed, which confirmed that the distribution of variables did not match the normal distribution. There were no significant relationships between nominal variables using the Chi-square test, and no significant intergroup differences (variable body modifications) were demonstrated by the $U$ Mann-Whitney test and the Kruskal-Wallis test. Finally, rho-Spearman correlation was performed to assess the relationship between variables.

\section{RESULTS}

Among respondents, i.e. 58 convicted men (age: $M=35.12$; $S D=10.98)$, average low scores were observed on the Group Identification Scale $(M=10.24 ; S D=9.86)$ and Identity Fusion Scale $(M=9.87 ; S D=11.29)$. The division of participants due to the nominal variable of possession of body modifications showed no significant differences in the results between respondents who had a tattoo/tattoos and those without body modifications.

The frequency of the sense of belonging to the group of 1) inmates and 2) families declared by prisoners is presented in the Tab. 1. A significant number of respondents felt a very weak sense of belonging with inmates (55.2\%) and a very strong sense of belonging with their family (44.8\%). Also, the distribution of both variables did not significantly differentiate participants who had body modifications from those who did not.

The relationships between the analysed variables were also verified; the results are presented in Tab. 2.

Significant relationships were observed between the Identity Fusion Scale and the following scales: Group Identification Scale, measure of identity fusion (sense of belonging with cellmates). Declarations of a stronger sense of belonging with fellow prisoners were associated with a higher identification with them $(r=0.43)$, as well as a fusion of identity $(r=0.53)$. Body modifications were not associated with the 
sense of belonging in a group, social identity or identity diffusion among the study participants. Significance at the statistical trend level was demonstrated between younger age and higher score on Identity Fusion Scale $(r=-0.26$; $p=0.051)$.

\section{DISCUSSION}

The obtained results indicate a significantly higher tendency among prisoners to declare a sense of belonging with their family rather than cellmates, to whom they usually feel very weak or weak attachment. The reluctance of convicts to perceive themselves through the prism of criminal identity may promote a more independent social identity. The scientific research on the prison environment focused mainly on the analysis of criminal identity. Especially, the self-concept plays an extremely important role in the likelihood and forms of a change in attitude when serving a sentence (Faine, 1973). The results emphasise the trend of importance of the family for most convicts.

The perceived bonds may form the basis for the rehabilitation process and help convicts achieve identity unrelated to criminal history. Identification with important groups should be treated as resources during rehabilitation (Ostermann and Matejkowski, 2014). In particular, experiments with a variety of activities allow convicts to test themselves in a new role. In the process of social re-adaptation, various methods can be used that enable the presentation of an alternative reality and available opportunities for convicts, with work used as one of the methods (Pstrąg, 2014). For instance, active participation in hospice volunteering (Witkowski, 2018) may complement social rehabilitation interactions in the form of charity work for the local community (Sokołowska, 2015). In addition, participation in a drama project significantly reduced the level of depression and problems with substance use (Mundt et al., 2020). A tendency that younger age may promote identity fusion was found in the study. Juvenile convicts may require the use of working methods suited to the possible threats and requirements. Research indicates that mindfulness and group identification foster self-control (Sroka et al., 2017).

Recognition of the importance of family during social rehabilitation interactions may significantly reduce the risk of recidivism in the future. Social stigmatisation of convicts was related to adaptation disorders by former prisoners after serving a sentence of imprisonment (Olszewska, 2012). Especially with the feeling of loneliness and lack of acceptance, which favours withdrawal from participation in social life and psychological isolation (Iwanowska, 2011; Moore and Tangney, 2017). The psychological and social consequences affect not only the convicts, but also their families. Individuals often struggle with the social stigma associated with the imprisonment of a family member. Efforts are increasingly being made to support convict's families (Bradshaw and Muldoon, 2020). Social work can be a source of benefits in promotion of correct behaviours, and support convicts and their families to regain respect and dignity (Mazza, 2008).

The limitation of the study was a relatively small group of respondents, which only allows to identify trends in the studied group. In addition, used questionnaires mainly focused on verifying group identification and identity fusion with fellow cellmates rather than family members. In future other personal resources that may differentiate convicts with/without body modifications should be considered. Body modifications did not affect group identification or identity fusion with inmates. Additionally, it would be worth analysing the actual functions of body modification among convicts and whether body modifications are an expression of personal identity or social identity, but possibly in relation to the family.

Briefly, personal resources, such as interpersonal relationships, should be treated as a potential in the rehabilitation process. Support should be provided also to the members of the convict's family. Age may be a risk factor for overidentification with fellow inmates, which should be confirmed in further research. However, formation of the non-criminal identity through nonstandard methods may allow to reformulate the image of themselves, and thus reduce the effects of perceived selves through the prism of the prisoner stereotype, which result from social stigma.

\section{Conflict of interest}

Author declared no potential conflict of interest.

\section{References}

Asencio EK: Familiarity, legitimation, and frequency: the influence of others on the criminal self-view. Sociol Inq 2011; 81: 34-52.

Bałandynowicz A: Reintegracja społeczna skazanych. Paradygmat tożsamości osobowej, społecznej i kulturowo-cywilizacyjnej. Polish Journal of Social Rehabilitation 2011; 2: 25-52.

Besta T, Gómez Á, Vázquez A: Readiness to deny group’s wrongdoing and willingness to fight for its members: the role of Poles' identity fusion with the country and religious group. Current Issues in Personality Psychology 2014; 2: 49-55.

Boduszek D, Adamson G, Shevlin M et al.: Criminal social identity of recidivistic prisoners: The role of self-esteem, family and criminal friends. J Police Crim Psychol 2013; 28: 15-25.

Boduszek D, Dhingra K, Debowska A: The Integrated Psychosocial Model of Criminal Social Identity (IPM-CSI). Deviant Behav 2016; 37: 1023-1031.

Bradshaw D, Muldoon OT: Shared experiences and the social cure in the context of a stigmatized identity. Br J Soc Psychol 2020; 59: 209-226.

Debowska A, Boduszek D, Sherretts N: Self-esteem in adult prison population: the development and validation of the Self-Esteem Measure for Prisoners (SEM-P). Deviant Behav 2017; 38: 1240-1251.

Faine JR: A self-consistency approach to prisonization. Sociol Q 1973; 14: 576-588.

Gómez A, Brooks ML, Buhrmester MD et al.: On the nature of identity fusion: insights into the construct and a new measure. J Pers Soc Psychol 2011; 100: 918-933.

Iwanowska A: Marginalizacja i wykluczenie społeczne skazanych na karę pozbawienia wolności - unormowania prawne służące jej ograniczeniu. Przegląd Więziennictwa Polskiego 2011; (71): 87-106. 
Jaśkiewicz M, Besta T: Is easy access related to better life? Walkability and overlapping of personal and communal identity as predictors of quality of life. Appl Res Qual Life 2014; 9: 505-516.

Kalinowski M, Niewiadomska I, Chwaszcz J et al.: Więzi społeczne zamiast więzień - wsparcie pozytywnej readaptacji osób zagrożonych wykluczeniem społecznym z powodu konfliktu z prawem. Raport z badań z rekomendacjami. Lublin 2010.

Kamiński MM: Gry więźniów: podział ról społecznych w instytucji totalnej. Studia Socjologiczne 2004; (3): 93-122.

Keith S, Scheuerman HL: The criminal self-view: how do identity discrepancies affect emotions and projected conformity among offenders? Sociol Inq 2018; 88: 576-598.

Kyprianides A, Easterbrook MJ, Cruwys T: "I changed and hid my old ways": how social rejection and social identities shape well-being among ex-prisoners. J Appl Soc Psychol 2019; 49: 283-294.

Mael F, Ashforth BE: Alumni and their alma mater: a partial test of the reformulated model of organizational identification. J Organ Behav 1992; 13: 103-123.

Mazza C: Within these walls: the effects of environment on social work practice in prisons. Practice: Social Work in Action 2008; 20 : 251-264.

Moore KE, Tangney JP: Managing the concealable stigma of criminal justice system involvement: a longitudinal examination of anticipated stigma, social withdrawal, and post-release adjustment. J Soc Issues 2017; 73: 322-340.

Mundt AP, Marín P, Gabrysch C et al.: Corrigendum: initiating change of people with criminal justice involvement through participation in a drama project: an exploratory study. Front Psychiatry 2020; 11: 139.

Niewiadomska I: Osobowościowe uwarunkowania skuteczności kary pozbawienia wolności. Wydawnictwo KUL, Lublin 2007.
Olszewska E: Stygmat przestępcy jako czynnik utrudniający readaptację społeczną byłych skazanych. Polish Journal of Social Rehabilitation 2012; 3: 173-186.

Ostermann M, Matejkowski J: Estimating the impact of mental illness on costs of crimes: a matched samples comparison. Crim Justice Behav 2014; 41: 20-40.

Pstrąg D: Praca w procesie readaptacji społecznej skazanych. Lubelski Rocznik Pedagogiczny 2014; 33: 148-164.

Sherretts N, Boduszek D, Debowska A: Exposure to criminal environment and criminal social identity in a sample of adult prisoners: the moderating role of psychopathic traits. Law Hum Behav 2016; 40: 430-439.

Sokołowska E: Praca charytatywna skazanych na karę pozbawienia wolności. Polish Journal of Social Rehabilitation 2015; 9: 55-67.

Sroka IM, Isemann SD, Walther E: With or without them: improving self-control in juvenile offenders. Basic Appl Soc Psych 2017; 39: $277-286$.

Swann WB Jr, Buhrmester MD: Identity fusion. Curr Dir Psychol Sci 2015; 24: 52-57.

Swann WB Jr, Gómez A, Seyle DC et al.: Identity fusion: the interplay of personal and social identities in extreme group behavior. J Pers Soc Psychol 2009; 96: 995-1011.

Vasquez EA, Wenborne L, Peers M et al.: Any of them will do: ingroup identification, out-group entitativity, and gang membership as predictors of group-based retribution. Aggress Behav 2015; 41: 242-252.

Witkowski R: Terapeutyczny wymiar wolontariatu hospicyjnego osób pozbawionych wolności. Państwo i Społeczeństwo 2018; 18: 121-138. 